\title{
Structuring and Management of Mount Kawi Cliff Temple Tourism Area, Tampaksiring Sub-district, Gianyar, Bali
}

\author{
Made Suryanatha Prabawa ${ }^{1}$, A.A. Gede Raka Gunawarman ${ }^{2}$, Ni Luh Anik Puspa Ningsih ${ }^{3}$ \\ \{1nathaprabawa.np@gmail.com $\}$ \\ 1,2Department of Architecture, Faculty of Engineering and Planning, Warmadewa University \\ ${ }^{3}$ Department of Management, Faculty of Economics and Business, Warmadewa University
}

\begin{abstract}
Gianyar Regency is one of the popular tourism destinations visited by international and domestic tourists. It provides variety of objects containing artistic, cultural, religious values, natural beauty, and historical artifacts. The wide landscape of rice fields, the beauty of the beach, as well as the creativity of arts and crafts are some of the cultural uniqueness in Gianyar Regency which makes it a tourist attraction. Tampak Siring is one of the sub-districts in this regency with the potential of being developed into a tourism due to the presence of Mount Kawi Cliff Temple (CTGK) which attracts both domestic and foreign tourists. They are also interested in the other attractions such as rice fields, the Tukad Pakerisan river area, and beautiful hiking trails. The management group of Bhuana Amertha Sari Village-Owned Business was interested in redeveloping and expanding the CGTK Tourism Area. However, due to the group's limitations, collaboration with the community service team of Warmadewa University is needed to help realize a more optimal area. Therefore, through service based on spatial-architectural and management, the CGTK is expected to provide a holistic planning in realizing a comfortable, beautiful, and cool tourism area.
\end{abstract}

Keywords : Candi Tebing Gunung Kawi, Travel Attractions, Structuring

\section{Pendahuluan}

Candi Gunung Kawi atau biasa disebut pula Candi Tebing Kawi adalah situs purbakala yang dilindungi di Bali. Terletak di Sungai Pakerisan, Dusun Penaka, Desa Tampaksiring, Kecamatan Tampaksiring, Kabupaten Gianyar, Provinsi Bali, Indonesia. Letaknya yang berdampingan dengan Pura Gunung Kawi, sungai, tebing terasering persawahan, membuat situs ini menjadi salah satu daya tarik wisata di kecamatan Tampak Siring. Menurut penelitian, 
candi ini dibuat pada masa pemerintahan Raja Udayana hingga pemerintahan anaknya yang bernama Anak Wungsu, tepatnya pada abad ke-11. Ditemukan pada tahun 1920 oleh peneliti asal Belanda, dan semenjak ditemukan penelitian terus dilakukan hingga saat ini (https://travel.kompas.com). Para wisatawan sangat menyukai objek ini karena mampu menyajikan kombinasi yang indah sehingga menghasilkan pemandangan yang menenangkan batin, melalui kombinasi hamparan sawah, gemericik air Tukad Pakerisan, dan berdirinya relief yang megah. Kegiatan yang biasa dilakukan oleh para wisatawan adalah bersantai, mengambil gambar lingkungan candi, dan menikmati sejarah dari tur guide yang ada. Keindahan potensi wisata bersejarah serta dikelilingi oleh lingkungan dan sumber daya manusia penunjang pariwisata, mengindikasikan bahwa kawasan Gunung Kawi perlu untuk ditata kembali sehingga mampu menjadi salah satu kawasan destinasi wisata terbaik di Gianyar kedepannya.

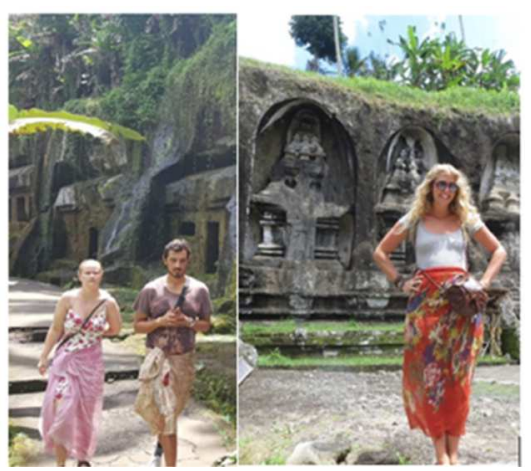

Gambar 1. Kunjungan Wisatawan ke Objek Wisata Candi Tebing Gunung Kawi Sumber : Dokumentasi Peneliti, 2019

Daya tarik wisata utama pada kawasan ini tentunya adalah Objek Candi Tebing Gunung Kawi, namun melihat dari ada banyaknya potensi wisata pendukung keberadaan Candi Tebing tersebut, alangkah baiknya jika dapat dikembangkan pula secara holistik sehingga Potensi Pariwisata dari objek lain yang ada disekitar Candi Tebing Gunung Kawi dapat terangkat dan kemudian satu per satu menjadi daya tarik wisata. Potensi-potensi wisata yang baru ditemukan baru-baru ini seperti area pinggiran sungai tukad pakerisan, persawahan di bagian selatan menghadap timur, air terjun, dan suasana alam sekitar yang nyaman dinikmati merupakan potensi yang sangat kuat didalam mengundang wisatawan untuk semakin banyak mengunjungi kawasan wisata ini,namun belum dapat ditata dengan optimal oleh pengelola.

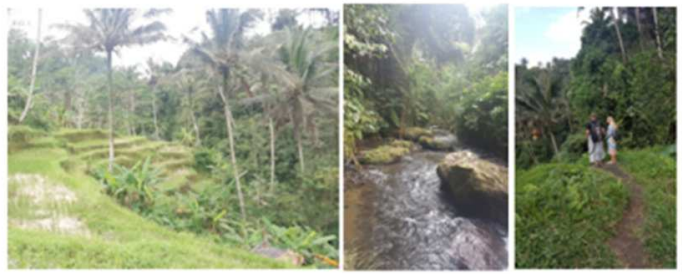

Gambar 2. Potensi Persawahan, Sungai Tukad Pakerisan, Jalur Lintas Alam Sumber : Dokumentasi Penulis, 2019

Dalam usulan Program kemitraan masyarakat ini, peran mitra dari pihak pengelola Kawasan Wisata CGTK ini menjadi bagian sangat penting, demi tercapainya tujuan pengembangan Kawasan Wisata Candi Tebing Gunung Kawi. Kawasan wisata CGTK ini berada dalam pengelolaan lembaga Badan Usaha Milik Desa (BUMDES) Bhuana Amertha 
Sari yang telah berjalan selama 1 tahun melakukan pembinaan, khususnya bagi unit-unit warung yang ada disekitaran Objek Wisata. Didalam terbentuknya BUMDES ini, dilandasi tujuan penyelenggaraan kemanfaatan umum dan mengembangkan perekonomian Masyarakat Sekitar yang berkepentingan dalam Kawasan Wisata CTGK. BUMDES Bhuana Amertha Sari merupakan mitra pengabdian ini dan bersama-sama dengan tim pengabdian akan berkolaborasi didalam menghasilkan rencana penataan dan pengelolaan Kawasan Wisata CGTK secara holistik (spasial dan sumber daya manusia).

Melihat fakta dari telah terbentuknya tim pengelola kawasan wisata tersebut maka dapat disimpulkan secara awal bahwa antusiasme didalam pengelolaan potensi sumber daya wisata secara mandiri dari masyarakat cukup kuat. Terlihat bahwa masyarakat memiliki niat yang tinggi yang kedepannya dapat menjamin penataan Kawasan Wisata Candi Tebing Gunung Kawi (CTGK) dapat berjalam sesuai rencana. Seperti yang dijelaskan berikut :

"Pengembangan desa wisata dapat berjalan sesuai dengan kebutuhan masyarakat, harus ada jaminan masyarakat untuk terlibat di dalamnya (Dewi, 2013: 117-226)".

Berawal dari niat dan sudah terbentuknya lembaga pengelola maka dapat dijelaskan bahwa partisipasi penuh masyarakat telah berlangsung. Diiringi dengan niat masyarakat yang tinggi, maka potensi, peluang, dan tantangan yang dimiliki sebuah kawasan dapat digubah menjadi sebuah rencana penatan yang baik. Pengembangan Kawasan Wisata CTGK berbasis penataan kawasan ini, maka harus dapat dimanfaatkan dengan sebaik-baiknya, serta perlu adanya jaminan keamanan bagi para wisatawan yang berkunjung ke daerah tersebut (Soebagyo. 2013:153-158). Namun dibalik lancarnya pengelolaan kawasan wisata dibutuhkan penataan dan pengelolaan yang terencana maupun tersistem dengan baik agar keberlanjutan kawasan wisata dapat berlangsung lama.

\subsection{Permasalahan Mitra}

Berdasarkan paparan pada analisis situasi diatas, sudah dapat dirumuskan beberapa permasalahan yang dialami oleh mitra. Secara umum mitra ini belum bisa bersinergi dengan baik karena beberapa faktor, seperti kurangnya perencanaan matang pengembangan Kawasan Wisata CTGK, sosialisasi kepada masyarakat sekitar yang masih sulit, manajemen pengelolaan area pariwisata, serta kurangnya pakar-pakar ahli yang terlibat di dalamnya. Secara terperinci permasalahan yang ditemukan dapat dijelaskan sebagai berikut :

\subsection{Permasalahan Utama :}

1. Belum adanya rencana penataan terkait potensi-potensi daya tarik wisata pendukung yang ada (persawahan, jalur lintas alam, sungai, dsb.) yang mampu menghadirkan potensi pariwisata sepenuhnya dari Kawasan Wisata CGTK.

2. Kurang dilakukannya kegiatan sosialisasi mengenai potensi pengembangan kawasan wisata kepada masyarakat serta bagaimana menjaga kawasan tersebut agar menjadi asri dan selalu ramai wisatawan.

3. Kurangnya lahan parkir menjadi permasalahan utama. Potensi Semakin dikenal dan semakin bertambahnya wisatawan yang berkunjung diiringi pula dengan jumlah kendaraan masuk yang bertambah, maka kedepannya lahan parker yang tersedia tidak mencukupi, sehingga berpotensi menimbulkan kemacetan saat puncak kunjungan wisatawan (high season) kunjungan. Ketidakberaturan Lapak Pedagang. 
4. Lapak berposisi tidak beraturan, yang bahkan berdiri di atas jalur hijau yang mana merupakan jalur subak yang dilindungi dan diakui UNESCO, jika tidak dilakukan sesuatu maka kedepannya para pedagang akan merusak keberadaan subak tersebut.

5. Belum ada sosialisasi terkait sistem manajemen dalam pembinaan pelaku ekonomi didalam Kawasan CGTK ini, sehingga potensi perekonomian berbasis pariwisata lokal belum maksimal dapat dihadirkan.

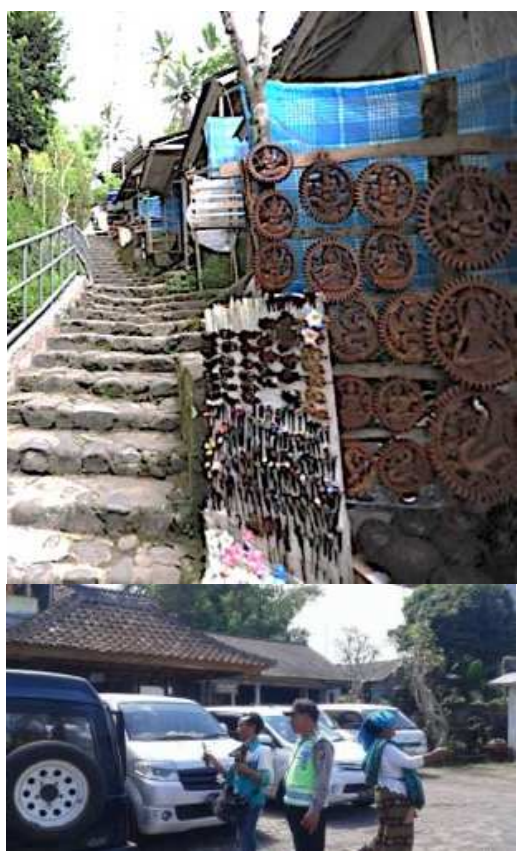

Gambar 3. Lapak Pedagang dan Lahan Parkiran Sumber : Dokumentasi Penulis, 2019

\subsection{Permasalahan Madya :}

Adanya Bangunan yang tidak termanfaatkan dengan baik, Bale yang ada pada area depan dekat tangga menurun menuju situs candi terlihat kosong tidak dipergunakan. Kedepannya keberadaan bale ini perlu dipikirkan kembali mengingat penempatannya yang kenyataannya kurang dibutuhkan. Jika ada bangunan lain dengan kasus yang sama maka berlaku pula hal yang sama yang mana

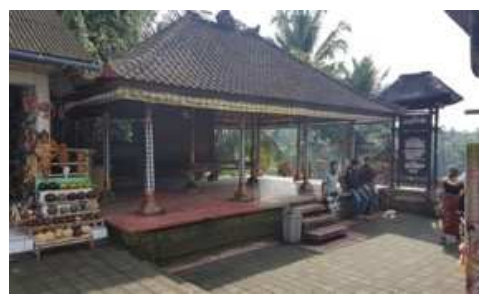

Gambar 1 Bangunan Bale yang Kurang Maksimal Dipergunakan Pada Area Masuk Kawasan Sumber : Dokumentasi Penulis, 2019

\subsection{Solusi Penataan (Spasial - Arsitektural)}


Penataan Kawasan Wisata CGTK ini akan direncanakan dalam bentuk Penyusunan Masterplan Penataan. Dalam masterplan ini akan diawali dengan penyusunan (1) Konsep Dasar dan Tema dari penataan yang menyesuaikan dengan kondisi keadaan eksisting yang mana cenderung mengarah pada konsep "Kebangkitan Potensi Alam Baru sebagai Daya Tarik Wisata" yang didukung tema penataan Arsitektur Ekologis. Menurut Frick (2007), Arsitektur Ekologis adalah arsitektur yang dihadirkan melalui perencanaan yang meniru atau memanfaatkan siklus peredaran alam yakni :

1. Intensitas energi baik yang terkandung dalam bahan bangunan maupun yang digunakan pada saat pembangunan harsu seminimal mungkin.

2. Kulit bangunan (dinding dan atap), hadir sesuai dengan tugasnya yakni melindungi bangunan dari sinar panas, angin, hujan.

3. Bangunan sebaiknya diarahkan menurut orientasi timur-barat dengan bagian utara/selatan menerima cahaya alam tanpa kesilauan

4. Bangunan sebaiknya dibuat sedemikian rupa sehingga dapat menggunakan penyegaran udara secara alamiah, dan memanfaatkan angin sepoi-sepoi untuk membuat ruangan dalam bangunan menjadi sejuk.

Prinsip-prinsip yang mendasari tindakan perencanaan diatas adalah :

1. Sedapat mungkin diupayakan agar struktur masyarakat dan penggunaan ruang tidak mengalami perubahan.

2. Persyaratan mutlak kegiatan ekonomi, terutama pembagian kerja dan pertukaran kerja, tidak akan terganggu.

3. Penggunaan ruang/lahan sebagai tempat pertanian, pedesaan, dan perkotaan yang memiliki hubungan timbal-balik akan dipertahankan.

4. Adat istiadat, tingkah laku, dan gaya hidup masyarakat yang tidak akan diubah.

(2) Tema dan konsep ini selanjutnya akan diaplikasikan dalam perencanaan zoning (penataan area) yang disesuaikan dengan keadaan eksisting dan yang paling optimal sehingga Kawasan Wisata tetap terjaga kesucian dan kelestariannya. Luaran dari langkah ini adalah lahirnya dokumen perencanaan zoning Kawasan Wisata CGTK baik Zoning Makro maupun Mikro. (3) Setelah Zoning tersusun, maka akan dilakukan penataan melalui tindakan perencanaan yang dibutuhkan baik arsitektural maupun lansekap guna mengangkat potensi daya tarik wisata khususnya pada potensi-potensi yang baru ditemukan. Perencanaan ini akan menghasilkann luaran dokumen gambar konsep desain bangunan fisik dan lansekap. Secara keseluruhan pada tahap akhir, Masterplan dapat tersusun dengan susunan Kajian, Solusi Penataan berupa Zoning, Desain Fasilitas, dan Desain Lansekap Pariwisata.

\subsection{Solusi Pengelolaan (Ekonomi Manajemen):}

Penyusunan sistem tata kelola yang optimal. Luaran dari solusi manajemen adalah peningkatan kinerja usaha dan kesejahteraan masyarakat. Peningkatan kinerja usaha dapat diukur melalui pertumbuhan omset penjualan, pertumbuhan asset, pertumbuhan laba yang dihasilkan serta jumlah kunjungan wisatawan ke desa, jumlah permintaan produk. Kesejahteraan masyarakat dapat diukur melalui jumlah pendapatan dan berkurangnya masyarakat yang menganggur.

\section{Hasil Kegiatan}

\subsection{Analisa SWOT Potensi Wisata Baru}


Berdasarkan gambaran umum dan identifikasi masalah maka dirasa perlu untuk melakukan analisisi SWOT terkait strategi pengembangan Kawasan wisata Candi Tebing Gunung Kawi khususnya dalam hal peningkatan potensi melalui penataan. Penataan dalam hal ini berkaitan dengan lahan, arsitektur, dan SDM (sumber daya manusia) yang menggunakan area objek wisata sebagai tempat aktivitas mereka. Strategi-strategu selanjutnya akan diterjemahkan dalam skenario penataan khususnya berkaitan dengan pengadaan atraksi wisata baru yang disesuaikan dengan temuan potensi wisata

\subsection{Kajian Potensi Wisata Baru}

Pada bagian ini akan lebih banyak membahas mengenai potensi baru yang ditemukan sebagai hasil survey mengelilingi lingkungan sekitar objek wisata Gunung Kawi. Berdasarkan survey yang dilakukan keseluruhan potensi tergolong sebagai potensi alam. Potensi alam tersebut diantaranya adalah sungai, air terjun, dan persawahan yang mana memiliki daya tarik sendiri dan sesuai untuk dikategorikan sebagai potensi. Potensi yang selanjutnya dalam tahap scenario dikembangkan menjadi sebuah atraksi wisata baru di kawasan objek wisata Gunung Kawi.

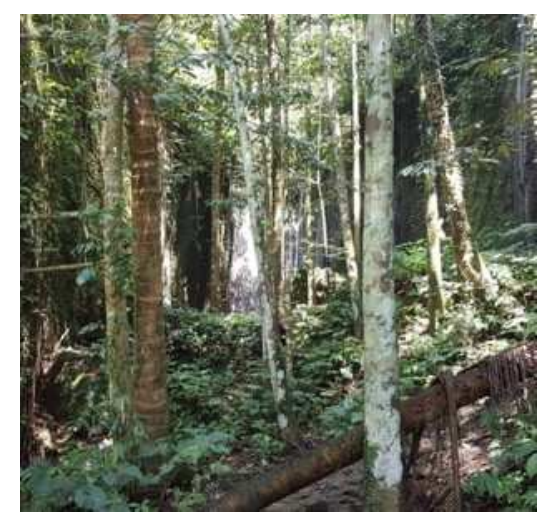

Gambar 2 Potensu Air Terjun Barat Sumber : Dokumentasi Penulis, 2019

Air Terjun Barat (Jalan menuju Candi 1)Berlokasi di sebelah barat Pura Gunung Kawi ditengah hutan tepatnya jalan menuju ke Candi 1. Untuk menuju air terjun ini diawali dengan berjalan melewati hutan yang dapat pula menjadi daya tarik sebelum menikmati pemandangan air terjun. Area ini dapat menjadi atraksi tracking dan rest area.

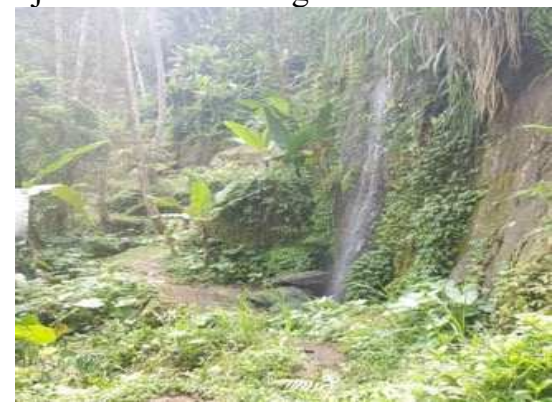

Gambar 3 Potensu Air Terjun Timur Sumber : Dokumentasi Penulis, 2019 
Air terjun Timur ini tergolong kecil, berposisi bersebelahan dengan jalan setapak (tracking) jalan baru dari Pura Melanting menuju Bukit Gundul. Air terjun ini dapat menjadi lokasi rest area atraksi tracking dengan view terasering sawah disisi utara.

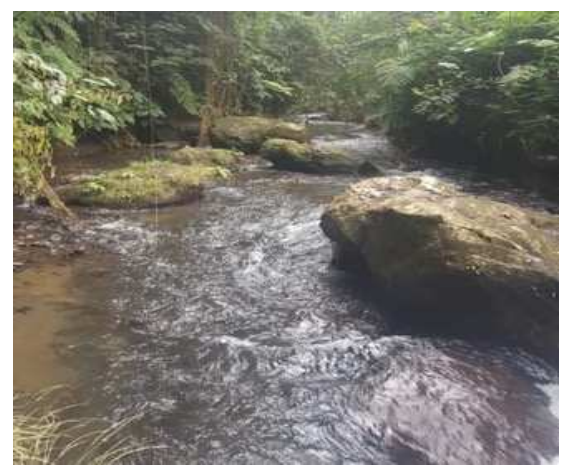

Gambar 7 Potensu Sungai Pakerisan Sumber : Dokumentasi Penulis, 2019

Sungai Pakerisan memiliki air yang cukup jernih dihiasi batu-batu kali besar dan tebing penuh tanaman dan pepohonan memberikan nuansa alami yang kental. Potensi sungai ini dapat dimanfaatkan sebagai view utama saat melewati jembatan baru.

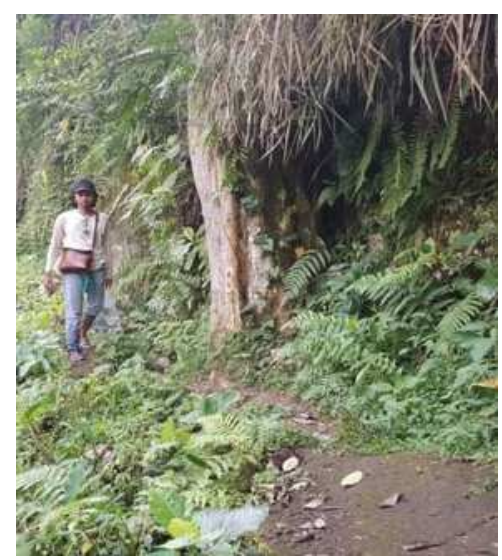

Gambar 8 Potensi Jalan Setapak Melanting-Bukit Gundul Sumber : Dokumentasi Penulis, 2019

Rencana jalur tracking baru melanting-bukit gundul memiliki potensi jalan setapak yang sudah siap ditata sebagai jalur baru. di sepanjang jalan ini dapat dilihat beberapa pohon besar, persawahan dan air terjun yang kecil 


\subsection{Gagasan Konsep Dasar dan Tema}

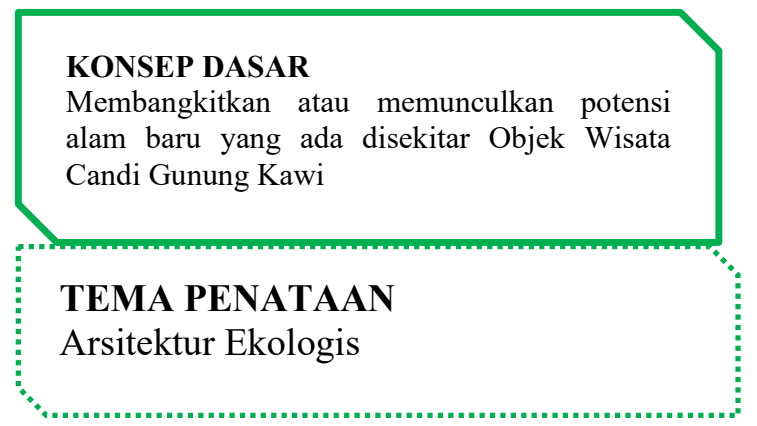

Rumusan Konsep dan Tema :

- Ditemukannya beberapa potensi wisata baru atau daya tarik wisata baru disekitar objek dapat dimanfaatkan sebagai nilai penunjang objek wisata utama. Berdasarkan pemikiran ini potensi-potensi tersebut akan ditata untuk dapat memenuhi persyaratan sebagai titiktitik objek wisata penunjang yang layak dikunjungi.

- Melalui tema arsitektur ekologis, yakni arsitektur yang lebih berpihak pada lokalitas alam tentunya akan membuat penataan bersifat ramah lingkungan, sekaligus memberikan edukasi tidak langsung pada wisatawan mengenai pentingnya menjaga lingkungan jika sudah terbangun nantinya.

Melalui penggunaan konsep dan tema, diharapkan objek wisata Gunung Kawi dapat menjadi salah satu tujuan favorit wisatawan jika akan menuju kabupaten Gianyar. Melalui wisata budaya, sejarah, masyarakat, dan alam yang bersinergi diharapkan pula mampu menjadi daya tarik yang unik dan memikat bagi para wisatawan

\subsection{Penyusunan Masterplan Penataan}

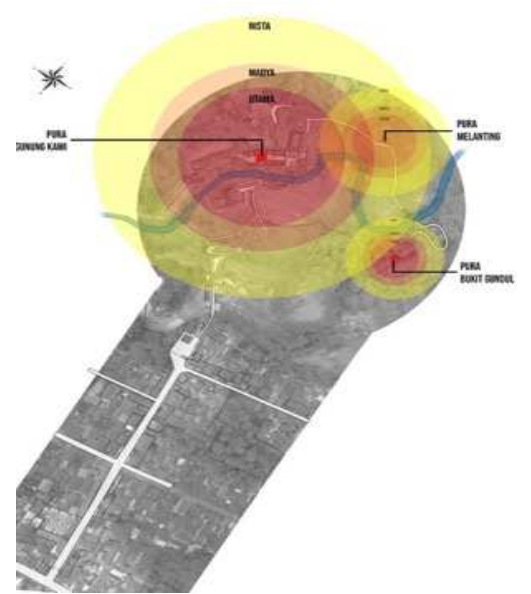

Gambar 9 Penzoningan Tri Mandala Area Pura Sumber : Ilustrasi Penulis, 2019

Pada Kawasan Wisata Candi Tebing Gunung Kawi, zoning utama difokuskan pertama dengan mengelompokkkan area-area lokasi situs-situs peninggalan bersejarah dan disucikan hingga kelompok area yang bersifat kurang suci (profan). Langkah zoning mengadopsi konsep 
penataan ruang tradisional bali pengkhususan area Pura yakni Tri Mandala: Utama Mandala, Madya Mandala, Nista Mandala.

\begin{tabular}{lll}
\hline Mandala & Norma/Regulasi & Nama Lokasi \\
\hline Utama & Aturan & Candi Kelompok 5 \\
Mandala & $\begin{array}{l}\text { Pengunjung/Wisat } \\
\text { awan Sangat Ketat }\end{array}$ & $\begin{array}{l}\text { Candi Kelompok 4 } \\
\text { Pura Melanting } \\
\text { Kawasan Candi 1 ( Bukit Dugul) }\end{array}$ \\
Madya & Aturan & Kawasan Sekitar Candi 1 \\
Mandala & Pengunjung & \\
Nista & Cukup Ketat & Aturan \\
Mandala & $\begin{array}{l}\text { Pengunjung } \\
\text { Longgar }\end{array}$ & Area Pedagang \\
& & \\
\hline
\end{tabular}

Dengan diberlakukannya zona mandala ini diharapkan kedepannya kunjungan wisatawan kedalam area utama atau zona utama Kawasan wisata Candi Tebing Gunung Kawi dapat lebih tertib khususny terkait menjaga kesucian dan taksu dari Pura-pura yang ada, dan juga kepada para masyarakat yang juga memanfaatkan zona ini menjadi lebih disiplin sehingga kedepannya Kawasan wisata dapat terpelihara eksistensinya

Setelah merumuskan zona-zona diatas maka langkah selanjutnya adalah merumuskan rencana penataan potensi-potensi wisata baru, penataan fasilitas wisatawan, dan penataan objek-objek yang sudah ada guna meningkatkan nilai kepariwisataan dari objek-objek atau daya Tarik wisata yang sudah ada sehingga dapat mengoptimalkan kunjungan wisatawan menuju Kawasan Wisata Candi Tebing Gunung Kawi.

\begin{tabular}{|c|c|c|}
\hline No & Rencana Penataan & Tujuan \\
\hline 1 & $\begin{array}{l}\text { Perencanaan } \\
\text { Sirkulasi }\end{array}$ & $\begin{array}{l}\text { Sirkulasi Kendaraan Pariwisata lebih optimal; Mengurangi kemacetan saat } \\
\text { High-Season; }\end{array}$ \\
\hline 2 & $\begin{array}{l}\text { Perencanaan Jalur } \\
\text { Pedestrian }\end{array}$ & $\begin{array}{l}\text { Penambahan Atraksi Wisata Tracking Menyusuri Daya Tarik Wisata Baru } \\
\text { yang ditemukan }\end{array}$ \\
\hline 3 & $\begin{array}{l}\text { Perencanaan River } \\
\text { View Deck }\end{array}$ & Penambahan Atraksi Wisata Menikmati keindahan aliran sungai Pakerisan \\
\hline 4 & $\begin{array}{l}\text { Perencanaan } \\
\text { Anjungan Selatan }\end{array}$ & Penambahan Atraksi Wisata Kekinian yakni Anjungan sebagai Spot Photo \\
\hline 5 & $\begin{array}{l}\text { Perencanaan Area } \\
\text { Kuliner Bali }\end{array}$ & $\begin{array}{l}\text { Penambahan Atraksi Wisata Kuliner, dengan penataan area khusus kuliner } \\
\text { dalam Kawasan Candi Tebing Gunung Kawi }\end{array}$ \\
\hline 6 & $\begin{array}{l}\text { Perencanaan } \\
\text { Entrance }\end{array}$ & $\begin{array}{l}\text { Perencanan Bentuk Pintu Masuk Utama yang nyaman dipandang dan } \\
\text { mampu mewakili Kawasan Candi Tebing Gunung Kawi itu sendiri dalam } \\
\text { memberikan gambaran awal bagi wisatawan yang berkunjung. }\end{array}$ \\
\hline 7 & $\begin{array}{l}\text { Perencanaan } \\
\text { Jembatan Baru }\end{array}$ & $\begin{array}{l}\text { Pembangunan jembatan agar integrasai antara objek wisata lama dengan } \\
\text { potensi wisata baru yang ditemukan dapat terjalin ( Pura Melanting } \\
\text { dengan Candi 1) }\end{array}$ \\
\hline 8 & Penataan Lobby & $\begin{array}{l}\text { Penataan lobby penerima wisatawan yang layak, sekaligus sebagai } \\
\text { tourism centre }\end{array}$ \\
\hline 9 & $\begin{array}{l}\text { Perencanaan } \\
\text { Central Parkir Baru }\end{array}$ & $\begin{array}{l}\text { Penambahan lahan parkir sebagai antisipasi peningkatan jumlah } \\
\text { kunjungan. }\end{array}$ \\
\hline 10 & $\begin{array}{l}\text { Penataan Ulang } \\
\text { Central Parkir Lama }\end{array}$ & $\begin{array}{l}\text { Penataan kembali toko-toko sehingga pada central parkir ini dapat } \\
\text { memberikan gambaran awal kawasan wisata Candi Tebing Gunung Kawi }\end{array}$ \\
\hline
\end{tabular}




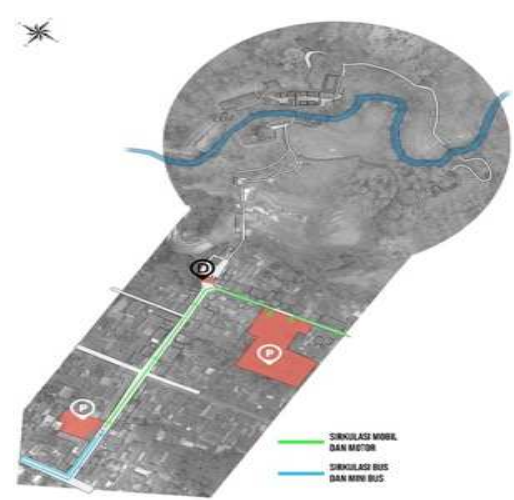

Gambar 4 Perencanaan Jalur Sirkulasi Sumber : Ilustrasi Penulis, 2019

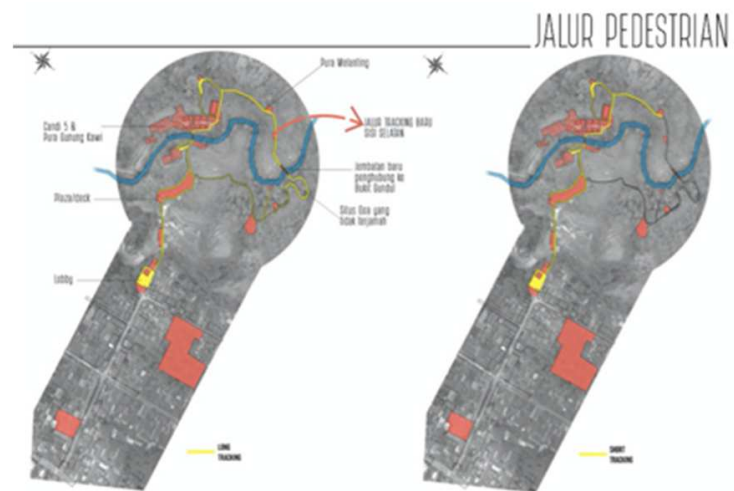

Gambar 5 Perencanaan Jalur Pedestrian (Short Tracking and Long Tracking) Sumber : Ilustrasi Penulis, 2019

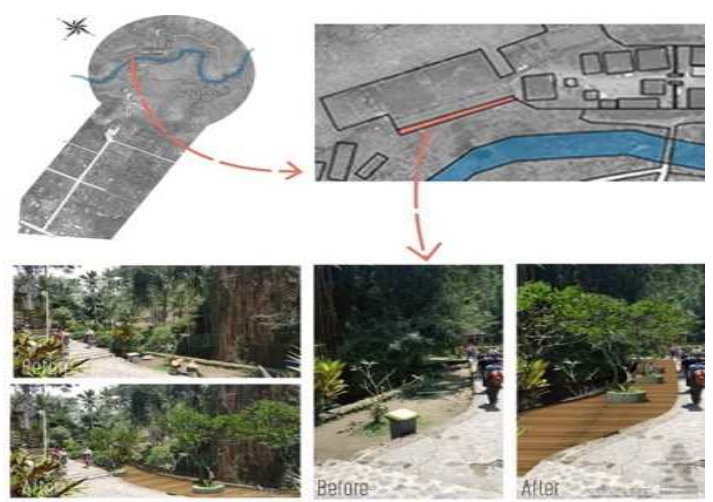

Gambar 6 Perencanaan River View Deck Candi 5 Sumber : Ilustrasi Penulis, 2019 


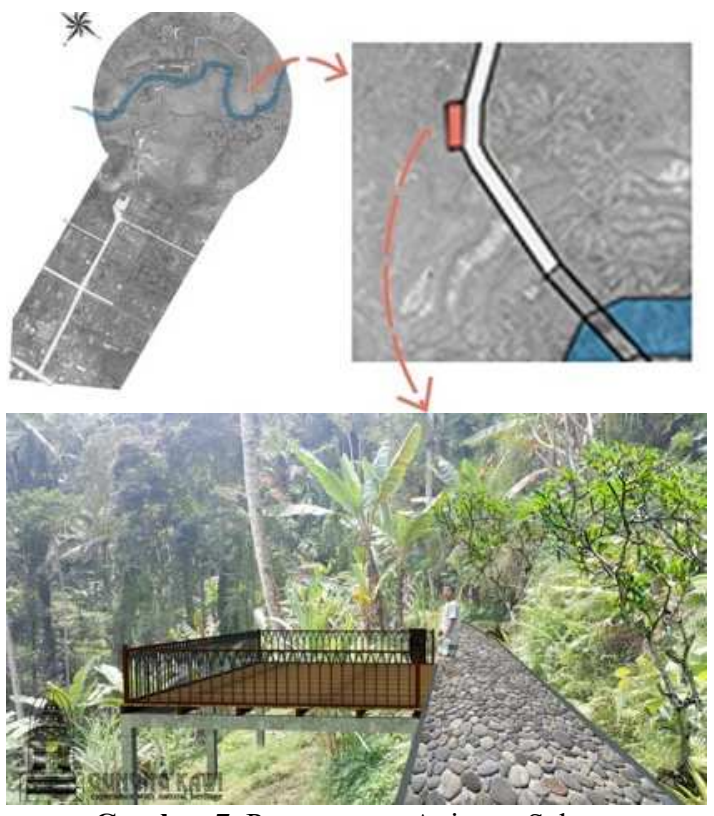

Gambar 7. Perencanaan Anjugan Selatan Sumber : Ilustrasi Penulis, 2019
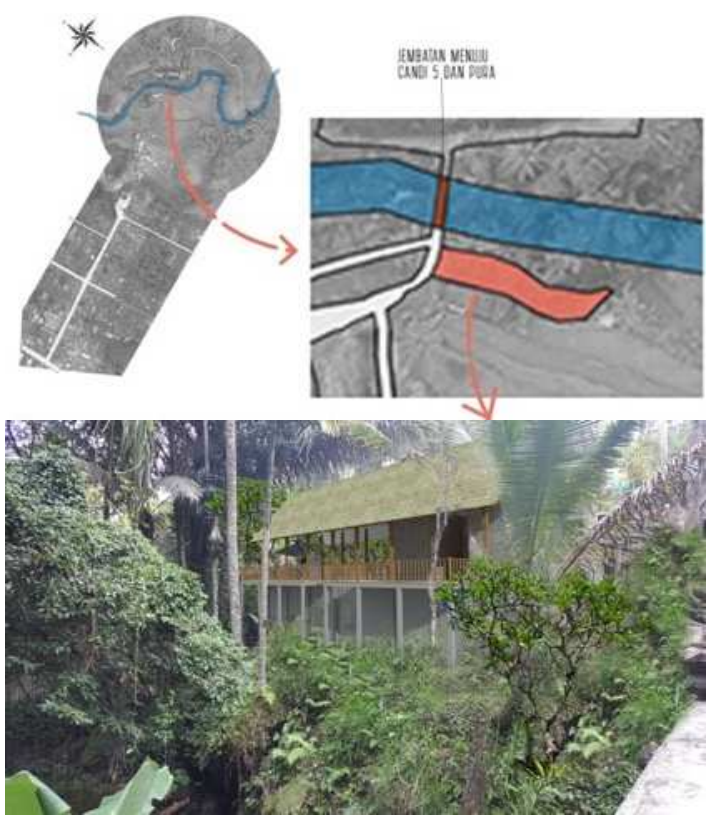

Gambar 8 Perencanaan Area Kuliner Bali

Sumber : Ilustrasi Penulis, 2019 


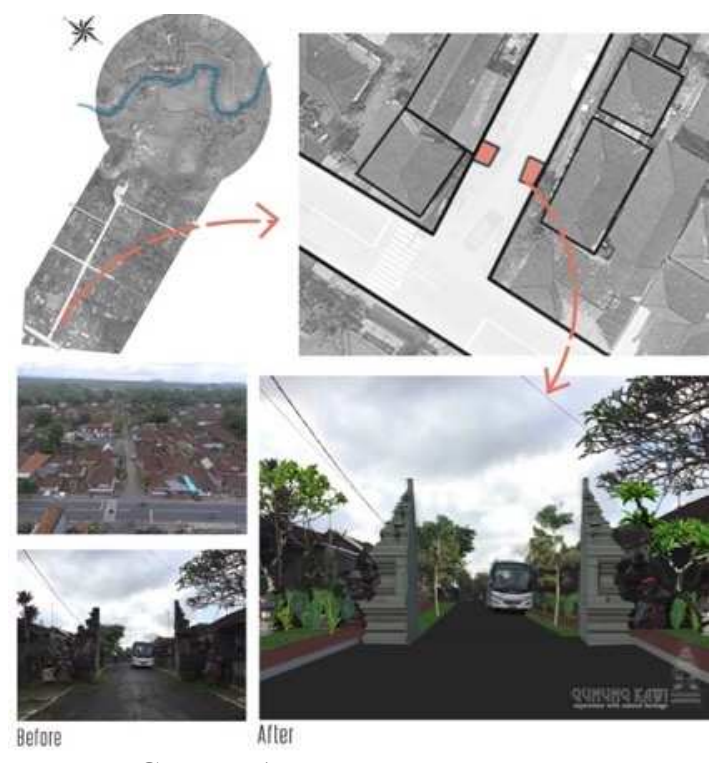

Gambar 15. Perencanaan Entrance Sumber : Ilustrasi Penulis, 2019

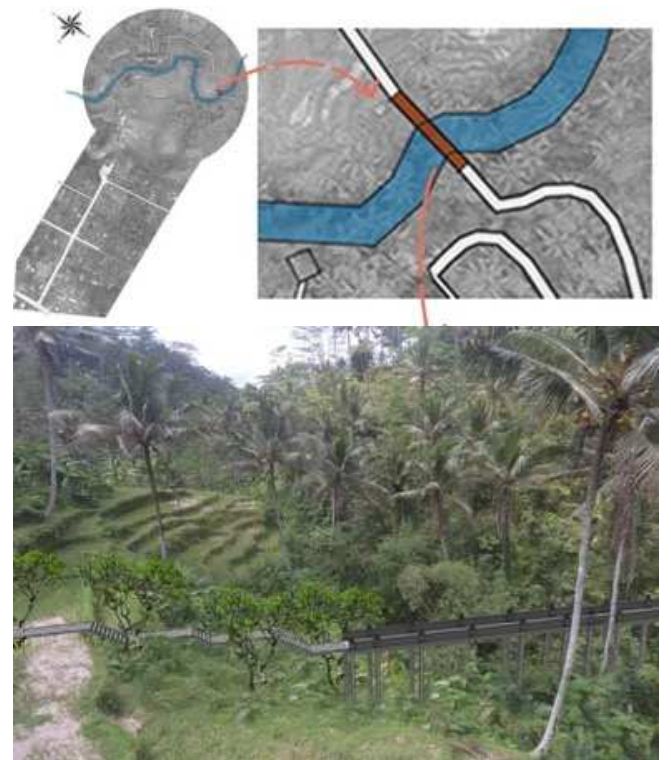

Gambar 9. Perencanaan Jembatan Baru Sumber : Ilustrasi Penulis, 2019 


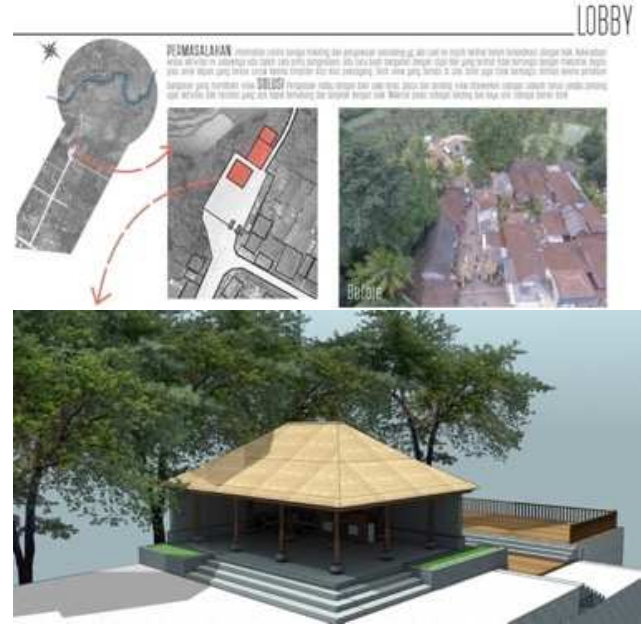

Gambar 10 Perencanaan Penataan Lobby Sumber : Ilustrasi Penulis, 2019

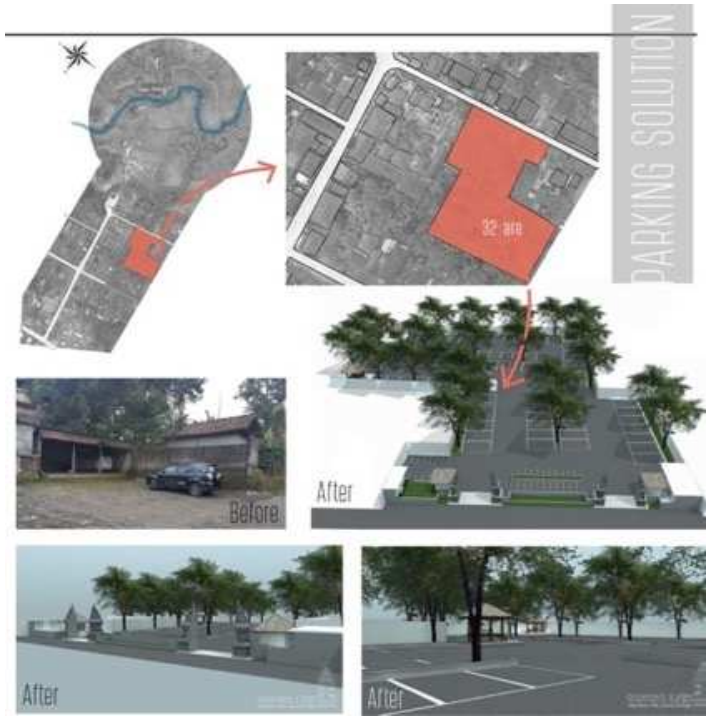

Gambar11 Perencanaan Penataan Central Parkir Baru Sumber : Ilustrasi Penulis, 2019 


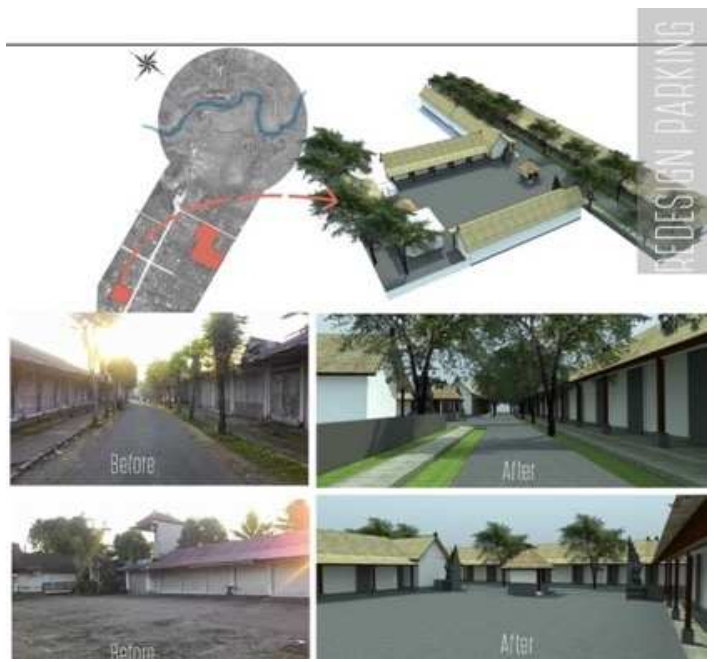

Gambar 12 Perencanaan Penataan Central Parkir Lama Sumber : Ilustrasi Penulis, 2019

\subsection{Penyusunan Skema Tata Kelola}

Dalam mendukung perkembangan dari Kawasan Wisata Candi Tebing Gunung Kawi Kedepannya dirasa perlu juga untuk dilakukan pengembangan terkait tata kelola dari Kawasan Wisata Tersebut. Skema pengelolaan dicoba untuk disusun dan diberikan pada pengelola dan segenap stakeholder dengan harapan dapat membantu proses pengelolaan yang lebih nyaman.

Permasalahan terkait tata kelola sering dikeluhkan oleh mayoritas stakeholder yakni khususnya adalah masyarakat, pemerintah desa, dan BUMDES, karena pengelola lama cenderung kurang memperhatikan kenyamanan wisatawan dan kurang memiliki inovasi terkait pengembangan Kawasan Wisata Candi Tebing Gunung Kawi Kedepannya. Dengan adanya rencana penataan Kawasan ini, dan hadirnya Nuansa Baru Pariwisata di Candi Tebing Gunung Kawi, para stakeholder juga berharap dapat memiliki sistem pengelolaan yang lebih baik dan terkoordinasi dengan jelas, dan terutama kedepannya terkait eksistensi Kawasan Wisata dapat melakukan pengembangan yang optimal.

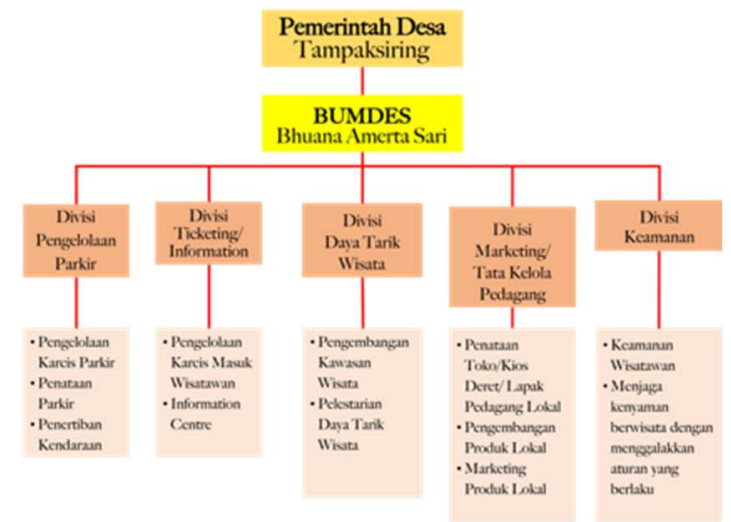

Gambar 13 Skema Organisasi Pengurus Sumber : Ilustrasi Penulis, 2019 
Dengan dibuatkannya skema organisasi yang baru dengan pemerintah desa sebagai penanggungjawab utama dan pihak BUMDES sebagai pengelola beserta divisinya diharapkan akan mampu meningkatkan pengembangan Kawasan wisata Candi Tebing Gunung Kawi kedepannya. Dengan Tupoksi ( Tugas Pokok dan Fungsi ) yang secara jelas tertulis dan harus dijalankan akan memberikan profesionalitas tersendiri bagi pengelola dimata wisatawan, sehingga wisatawan akan semakin merasa nyaman dan aman berwisata di Kawasan Wisata ini.

Melalui skema koordinasi puncak pemerintah desa Pengembangan Kawasan Wisata kedepannya akan dapat bersinergi dengan program-program pengembangan dari Pemerintah Kabupaten Gianyar, melalui Dinas Pariwisata. Dengan demikian, jika memiliki rencana pengembangan kembali kedepannya dapat memperoleh bantuan dana dari pemerintah.

\section{Kesimpulan}

Tersusunnya rencana penataan dan pengelolaan daripada Kawasan Wisata Candi Tebing Gunung Kawi merupakan langkah awal dari pengembangan. Melalui bebrapa pembahasan rencana penataan dan pengelolaan sebelumnya dapat disimpulkan bahwa:

1. Keberadaan Kawasan Suci Candi Tebing Gunung Kawi harus tetap dapat terjaga melalui Zoning guna mempertahankan eksistensi pura kedepannya terkait kemungkinan terus berkembangnya pariwisata di Kawasan ini.

2. Penataan dengan tidak mengubah susunan alam merupakan bentuk pengembangan Kawasan wisata yang bersifat ramah lingkungan namun tetap menambah nilai ekonomi dengan adanya penambahan daya Tarik wisata baru.

3. Penataan sirkulasi agar tidak terjadi kemacetan saat high-season merupakan langkah penting agar tidk menyumbang kemacetan kendaraan hingga jalan utama (jalan raya tampaksiring).

4. Peningkatan kenyaman wisatawan dengan menambahkan area parkir, sekaligus menambahkan pemasukan bagi pengelola disamping karcis masuk.

5. Sistem tata kelola baru dapat memaksimalkan kinerja pengelola yang didalamnya terdiri atas masyarakat Desa Tampaksiring dalam usaha mandiri mereka mengelola dan mengembangkan Kawasan wisata milik Desa mereka sendiri kedepannya.

6. Fasilitas-fasilitas yang baru dan daya Tarik wisata baru yang hadir melalui rencana penataan, menjadi sebuah dasar untuk melakukan pengembangan Kawasan Wisata kedepannya dan sebagai bagian dari aspirasi aktif-kreatif masyarakat setempat.

Kehadiran dokumen penataan dan pengelolaan ini diharap mampu membantu pihak pengelola dalam usaha meningkatkan kunjungan wisatawan, namun untuk dapat mencapai hasil akhir yang diinginkan sesuai dengan rencna penataan dan pengelolaan Kawasan dibutuhkan sinergi yang kuat antara para stakeholder terkait koordinasi dan tugas-tugas di lapangan 


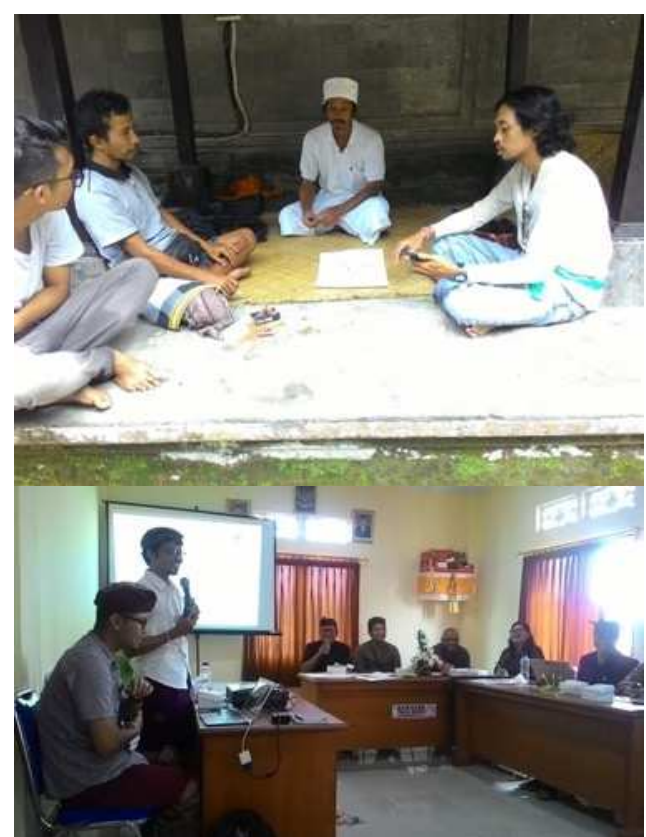

Gambar 14 FGD dengan Mitra, Masyarakat, dan Insransi Pemerintah Sumber : Ilustrasi Penulis, 2019

\section{References}

[1] Dewi, Made Heny Urmila. 2013. Pengembangan Desa Wisata berbasis Partisipasi Masyarakat Lokal di Desa Wisata Jatiluwih Tabanan Bali, dalam Jurnal Kawistara volume no 2, 17 Agustus 2013. Yogyakarta : UGM

[2] Frick, Heinz; Suskiyanto, Bambang FX. 2007. Dasar-Dasar Arsitektur Ekologis : Konsep Pembangunan Berkelanjutan dan Ramah Lingkungan. Yogyakarta. Kanisius.

[3] Meliala, Andi Suranta ; Matondang, Nazarudin dan Sari, Rahmi M. 2014. Strategi Peningkatan Daya Saing Usaha Kecil dan Menengah (UKM) berbasis Kaizen. Jurnal Optimasi Sistem Industri, Vol.3 No.2 April 2014 : 641-664. ISSN 2088-4842

[4] Soebagyo. 2012. Strategi Pengembangan Pariwisata di Indonesia, dalam Jurnal Liquidity, volume 1 no 2, Juli-Desember 2012. Jakarta Selatan.

[5] Setyanto, Alief Rakhman ; Samodra, Bhimo Rizky dan Pratama, Yogi Pasca. 2015. Kajian Strategi Pemberdayaan UMKM dalam menghadapi Perdagangan Bebas Kawasan ASEAN. Etikonomi Vol 14 (2) Oktober 2015 P-ISSN : 1412-8969 ; E-ISSN : 2461-0771

[6] Sonalia, Devi dan Hubeis, Musa. 2013. Pengendalian Mutu Pada Proses Produksi di Tiga Usaha Kecil Menengah Tahu Kabupaten Bogor. Jurnal Manajemen dan Organisasi Vol IV No.2, Agustus 2013

[7] Utaminingsih, Adijati. 2016. Pengaruh Orientasi Pasar, Inovasi dan Kreativitas Strategi Pemasaran terhadap Kinerja Pemasaran pada UKM Kerajinan Rotan di Desa Teluk Wetan, Welahan, Jepara. Media Ekonomi dan Manajemen Vol.31 No.2 Juli 2016 P-ISSN : 0854-1442 EISSN : 2503-4460 